think customs agents are liars. We have enormous respect for customs agents and would, moreover, never lie to one. Ever.) Are they watching for tell-tale body language? Does scratching one's nose in a certain manner give away that one might have been born in or might have lived in Africa since 1977?

We aren't convinced that the nurses even look at the donors. Frankly, the confessional nurses seem bored. The old hands recite the questions, like experienced waiters rifling off the night's specials, but without any vocal inflection. In this setting the sex doesn't sound too exciting. Maybe the nurses should suggest wine pairings.

Also, why do we have to go through all the questions every single time, even though it may have only been a couple of months since the last donation? Some things can't have changed. Our grandmothers still were not born in Central America.

\section{A moment for self-reflection}

The questions posed by both Australian and Canadian blood donation organizations give occasion for self-reflection. Older Sarah varies between a holier-than-thou attitude ("Of course I have not paid for sex. I am hematologically pure!") and puzzlement (“Am I living life to its fullest?") Older Sarah notes that in Canada she's asked if she has had sex with someone born in Africa after 1977, which is actually kind of flattering - at least the Canadian Blood Services thinks she is attractive enough to hook up with a man 23 years her junior.

Younger Sarah, on the other hand, has felt a bit pathetic and judged while attempting to donate blood. In Australia (where, by the way, the nurses are referred to as "sister," which makes the event even more confessional) Younger Sarah had a moment that called into question both her character and her desirability.

"I bring your attention to item 10. You indicate that you have not had sex with a foreigner in 12 months. This question is meant for Australians. So, by answering this question, you are saying that you have not had sex with a Canadian in the past 12 months. You told me that you came to Australia only seven weeks ago, so this must be a lie." With her cheeks blazing crimson Younger Sarah stuck by her original answer.

"No, I have not had sex with a foreigner — not even a Canadian one." A look of pity crossed the sister's face. Younger Sarah was tempted to defend herself by explaining her "quality over quantity" approach to men. In the end, she had too much discretion. (We see an opportunity here. We would like to suggest that blood services start offering matchmaking to single donors. This would work as an incentive and, with a little planning, could help breed the next generation of most-needed blood types.)

\section{Questions above and below the equator}

Comparing the questions asked by Canadians with those asked by Australians reveals differences between our styles and our disease worries (Box 1). Australia has a cool question about abattoir work and asks about a disease we Sarahs had never even heard of: fatal familial insomnia. (We are pretty sure it doesn't end well, what with the "fatal" part, and all.) In Canada, on the other hand, we are very worried about monkey body fluids. Blood donors in Canada need to answer this ques-

\section{tion: Have you, in your past or present job, taken care of or handled monkeys or their body fluids? We have wondered: Who are these professional monkey handlers? Are there a lot of Canadians donating who are monkey laboratory techs, monkey trainers, The Man with the Big Yellow Hat? And what about people who handle monkey body fluids recreationally? Are they not of concern? We suppose at one level it makes sense. The Canadian questions suggest that sex for money is hemato- logically riskier than sex for fun (or social status or security or revenge on that "friend" who slept with your last boyfriend, but we digress.) We can accept that monkey body fluid handling for money could take one down a more sordid path, and the question will screen out the all-too-common monkey escort service provider. Speaking of monkeys, it is curious to think about where the degrees of separation stop. They care if you had sex with a man who had sex with a man, and they care if you are yourself a professional monkey body fluid handler, but not if you had sex with somebody who is a professional mon- key body fluid handler. Unless you paid him. \\ There is also an interesting intercultural difference in the questioning that explores for bisexuality. In Canada we ask female donors: In the last 12 months, have you had sex with a man who had sex, even one time since 1977 with another man? Clearly the message is: Tell us only if you KNOW he did. No surmising. In Australia, there is room for more judg- ment, as the question is: Have you had sexual activity with a male who you think might be bisexual? We picture the Aus- tralian Sheilas pondering before answering. "He did seem ter- ribly interested in my David Beckham calendar." \\ The greater good \\ In spite of the strangeness, the redundancy, and the judgement that come with blood donation, in the end it is all worth it. Why? In both countries you get cookies and juice. For being a first time donor in Australia, Younger Sarah also received a first aid kit and a shell with mother of pearl. And - blood donation burns calories! Really! We found on the Internet that donating blood burns about 650 calories. So you can eat the cookies and still lose weight doing this. \\ Oh yeah — you will also probably save somebody's life. \\ Sarah Shea MD O -ve}

Department of Pediatrics

Dalhousie University

Halifax, NS

Sarah Giles MD A +ve

Locum family physician

Northern Ontario and Western Australia

\section{Box 1: Sources}

- Australian Red Cross Blood Service Questionnaire: www.donateblood.com.au/files/images/Donor\%20 Questionnaire\%20sample\%20July\%202010.pdf

- Canadian Blood Services Donor Questionnaire: www.blood.ca/CentreApps/Internet/UW_V502_Main Engine.nsf/resources/Can-I-Donate/\$file/ROD_2010-01-27.pdf 